\title{
HISTOLOGICAL CHANGES IN THE TESTES OF THE FISH Gerres oyena (Forsskal, 1775) DURING THE REPRODUCTIVE CYCLE IN SUEZ BAY, RED SEA, EGYPT
}

\author{
Kamal F. EL-Boray \\ National Institute of Oceanography and Fisheries, Ataqa, Suez, Egypt
}

Key words: Gerreidae, Red Sea fish, Gerres oyena, histology testis, spermatogenesis,

\section{BSTRACT}

The fish Gerres oyena is distributed in different places of the world. 1 Few studies were carried out on this species, though it has important economic value in the fishery of the Red Sea. Moreaver, no previous wok on the reproductive cycle took place for such species. So this study was carried out to follow up the reproductive cycle and mode of reproduction of Gerres oyena. The fish samples were collected monthly from Suez Bay during the period from May/1997 to March/1998. The histological slides of testes showed five spermatogenetic cell types: namely: spermatogonia, primary spermatocytes, secondary spermatocytes, spermatids and spermatozoa. The maturation of the testes can be divided into eight stages, immature, developing virgin, maturing, mature, ripe, spawning, spent and developing recovery stages. Spawning occurred in July to late September. The discharge of sperms occurred as fractional manner. These results are useful in inducing spawning of this species.

\section{INTRODUCTION}

The fish $G$. oyena belongs to the family Gerreidae. It shares a considerable importance in the catch of the Suez Bay. There have been a number of histological studies on the testes of various species in the Red Sea, Gulf of Suez and Suez Bay (Siganus rivulatus, by ELMesiery, 1993; Mugil seheli by Zaki et al. 1994; Nemipterus japonicus, EL-Halfawy 1995; and Saurida undosquamis by Ramadan 1995). However to date, there has been no study undertaken on the cestes of $G$. oyerna in the Suez Bay.

This paper gives a description of the histological characters of testes of male $G$. oyena, to shed light on the seasonal changes and 
reproductive cycle. Hopefully, such study will be useful in the induction of spawning and in the management of this fish.

\section{MATERIAL AND METHODS}

G. oyena was sampled during the period from May/1997 to March/1998 in the Suez Bay. Testes were fixed in Bouin's solution, dehydrated, cleared and embedded in paraffin wax. Sections 5-6 $\mu \mathrm{m}$ thick were stained with Heidenhain iron hematoxylin and counter stained with eosin. The sections were investigated and the development of spermatogenic cells and maturity stages of testes were identified.

\section{RESULTS}

In the sections of the testes of $G$. oyena, the lobules were filled with discrete nests of spermatogenetic cells in various stages of maturation. Each nest of cells contains one spermatogenetic stage. In $G$. oyena five spermatogenetic cells were recognized:

(1) Spermatogonia

These cells are large; and have diameters varying from 6.38 to $10.2 \mu \mathrm{m}$. Each spermatogonium has a thin pale cytoplasm and a nucleus with a prominent nucleolus. These cells are attached to the lobule wall in all stages of maturation (Fig. 1).

(2) Primary spermatocytes

These cells, formed by mitotic division of spermatogonia occur in nests. They measure $3.83 \mu \mathrm{m}$ in diameter; their nuclei are smaller than that of the spermatogonia. They are densely stained and lack distinct nucleoli. The chromatin particles are equally scattered inside the nucleus, acquire a patchy appearance inside the nucleus (Fig. 2).

(3) Secondary spermatocytes

They are formed by meiotic division of the primary spermatocytes. The Secondary spermatocytes measure about $3.19 \mu \mathrm{m}$ in diameter. The nucleus of these cells is characterized by the homogeneity in staining and the chromatin is very dense. Nests of such cells are found at the periphery and in the central region of the lobules (Fig. 2).

(4) Spermatids

These cells are found in clusters in the lumen of the lobules.

They differ from other cells, where the membrane wall of the nests 
seems to be lacking. They measure about $2.5 \mu \mathrm{m}$ in diameter and have small and very dense chromatin granules (Fig. 3).

\section{(5) Spermatozoa}

The term spermiogenesis is the process of metamorphosis of Spermatids into sperms. This occurs in the lumen of lobules. The head of spermatozoan measures $1.9 \mu \mathrm{m}$. In the mature stage, the sperms are often organized into parachute-shaped clumps (Fig. 5).

\section{Histological categorization of maturity stages of male $G$. oyena}

The maturation of testes of $G$. oyena can be divided into eight stages. These are: immature, developing virgin, maturing, mature, ripe, spawning, spent and developing recovery.

\section{I-Immature stage}

In this stage, all lobules of the testis are formed of spermatogonia which acquire different sizes and are found in groups that fill the tubules lumina.

\section{II- Developing virgin}

The testes of this stage exhibit the incipient active spermatogenesis, where cysts of different stages of spermatogenetic cells are found inside the lobules. The spermatogonia decrease in numbers and line the wall of the lobule. Also cysts of primary spermatocytes, secondary spermatocytes and spermatids are found, but the secondary spermatocytes are predominant. Cysts of spermatids are found but are few (Fig. 2).

\section{III- Maturing stage}

This stage of maturation is characterized by the formation of the lobule lumen, where a small quantity of spermatozoa is seen. The spermatogonia and the primary spermatocytes become relatively few in number. The secondary spermatocytes are predominant in this stage.Also, groups of spermatids are found in the lobule lumen (Fig. 3).

\section{IV-Mature stage}

In this stage, the spermatozoa are predominant over all the earlier spermatogenetic cells (Fig. 4). The spermatozoa near the wall of the lobules form parachute shaped clumps, where as those found in the lumen of the lobules become separately free and fill it. Solitary spermatogonia are found at the periphery of lobules. 


\section{V-Ripe stage}

This is the stage where the lobules are packed with spermatozoa. The earlier spermatogenetic cells are very few in numbers and are found attached to the wall of the lobules (Fig. 6). VI- Spawning stage

At this stage, a considerable quantity of sperms are discharged; leading to a reduction in the lobules size. In the lumen of the lobules there are also a considerable quantity of sperms. The spermatogonia and the secondary spermatocytes increase in number. The walls of the lobules become loosely contracted and thicker than that of the preceding stages (Fig. 7).

\section{VII- Spent stage}

In this stage, some lobules contain residual sperms and others not. The wall of the lobules is very thick if compared with the preceding stages. The spermatogonia then increase in number (Fig. 8).

\section{VIII- Developing recovery}

In this stage, the testes enter the regeneration phase; only spermatogonia cells are shown inside the lobules. These cells arrange into two layers that line the wall of the lobules which becomes thin. The lumen of lobules appear empty of any cells (Fig. 9).

\section{Monthly distribution of maturity stages}

Fig. (10) shows the monthly distribution of maturity stages of testes of $G$. oyena. In May, the developing and maturing stages form $20 \%$ and $80 \%$ respectively. In June, 3 stages of maturation appear: maturing, mature and ripe; that are represented by $43.57 \%, 36.23 \%$ and $20.2 \%$ respectively. The start of spawning occurs in July, where the spawning stage is represented by $30.5 \%$ while the mature stage represents $34 \%$ and ripe stage represents $35.5 \%$. In. August, the spawning still occurs, where the spawning stage is represented by $30 \%$, while the ripe and spent stages, are represented by $30 \%$ and $40 \%$ respectively. In September, 2 stages of maturation are found, the spawning and the spent, which are represented by $22.5 \%$ and $74.5 \%$ respectively. From October to late December, all testes are found in spent stage. In January and February, the immature stage is represented by $14.29 \%$ and $69.32 \%$ respectively. Also the spent stages are represented by $85.71 \%$ and $30.77 \%$ respectively. In March, the testes reacquire their activity and enter the developing recovering stage by ratio of $31 \%$, while the other testes are found in immature and developing virgin stages by ratios of $25 \%$ and $44 \%$ respectively. 
Histological changes in the testes of the fish Gerres oyena

(Forsskal, 1775) during the reproductive cycle in Suez Bay, Red Sea

\section{DISCUSSION}

It is known that the basic and complementary tasks of the testes of teleosts are to produce fertilizable gametes (i.e., sperm), necessary for successful reproduction, and the pituitary-dependent synthesis and secretion of a variety of steroid hormones which regulate the development of germ cells. In $G$. oyena, the testes are elongated paired organs attached to the dorsal body wall. The most common arrangement of lobules would appear to be that of the radial type, which are converging on the spermatic duct. This arrangement has been described by Turner (1919), Lofts and Marshal (1957), Latif and Saady (1973), EL-Maghraby et al., (1981), Zaki et al., (1994), Asem (1995) and EL-Boray (1997). In G. oyena, the lobules run lengthwise with lateral communications, becoming evident during the prespawning and spawning periods, similar to the observation of Rastogi (1968).

In testis of $G$. oyena, five spermatogenetic cells are recognized, spermatogonia, primary spermatocytes, secondary spermatocytes, spermatid and spermatozoa. The formation of these cells occurs as asynchronous process in the lobules, where all these cells are found in one lobule. This phenomenon and the presence of different individuals at different maturity stages in the same period during spawning, in addition to the discharge of sperms in intermittently procedure lead to the conclusion that male $G$. oyena has a prolonged spawning season. Some authors found this peculiarity in other fishes, Latif and Saady (1973) in Tilapia nilotica, Asem (1992) in Oblada melanura, Zaki et al., (1994) in Mugil seheli and EL-Boray (1997) in Rhabdosargus haffara. From the histological sections of testes and from the distribution of maturity stages during the period of study, it is obvious that the spawning season of male G. oyena occurs from July to late September. El-Boray \& EL-Gharabawy (1999) found that the spawning season of female $G$. oyena occurs from June to early September. So, the male $G$. oyena starts its spawning season later than that of female by one month.

The testes of $G$. oyena have a period of quiescence from October to February; while in March, the spermatogonial activity starts. This agrees with EL-Mesiry (1993) in Siganus rivulatus of the Red Sea, where it had a quiescent period from August to February. Dadzie (1969) in Tilapia mossambica found that spermatogonia proliferation began shortly after the period of functional maturity and 
continued during the winter and summer months, so there is no quiescent period.

In spent stage of $G$. oyena, residual sperms are found in the lumen of lobules, but in the developing recovery stage, the lumen is empty. In contrast to this finding, Pollard (1972) in Galaxias maculatus found that in the spent stage, there were large amounts of residual sperms in the lobules. These sperms remain in the testis lobules, of at least some of the survivors of the previous spawning season, even up to the time of sperm production in the following maturation cycle.

On the other hand, Henderson (1962) found that in Salvelinus fontinalis, after completion of the spawning season, "phagocytes invade the lumen of the testis lobules and sperm ducts and ingest the residual sperm". In $G$. oyena no phagocytosis was observed. This is in agreement with that of Zaki et al., (1994) and EL-Boray (1997).

Teleost spermatozoa lack an acrosome, which occurs in all other vertebrate groups. This may be related to the presence of a micropyle in teleost eggs, which insures sperm penetration (Grier (1981) and Nagahama (1983). Moreover, Grier (1981) showed that sperm morphology reflects the mode of fertilization. The so-called primitive type of sperm belongs to aquatic species with external fertilization. These sperms typically have a spheroidal nucleus with a short middle piece. The spheroidal nucleus of this type characterises the sperm of $G$. oyena. Sperm in species with internal fertilization are typically slender and elongate in form.

In $G$. oyena, the ripe male contains a very few number of spermatogonia, but after the end of spawning season, this number increases and arranges in two rows lining the wall of lobules. So, it is believed that the renewal of spermatogonia is derived from the reserve spermatogonia present in the testis. This supports the findings of Asem (1992) in Oblada melanura, Zaki et al., (1994) in Mugil seheli and EL-Boray (1997) in Rhabdosargus haffara. 


\section{REFERENCES}

Asem, S. S. A. (1992): Reproductive biology and physiology of one species of family Sparidae in Mediterranean Sea. M. Sc. Thesis, Faculty of Science, Alexandria University.

Asem, S. S. A. (1995). Reproductive biology and induced spawning of Solea species. Ph. D. Thesis, Faculty of Science, Alexandria University.

Dadzie, S. (1969): Spermatogenesis and stage of maturation in the male Cichlid fish, Tilapia mossambica. J. Zool. London., 159: 399-403.

El-Boray, K. F. M. (1997): Reproductive biological studies on Rhabdosargus haffara in different water fish farms. Ph. D. Thesis, Faculty of Science, Zagazig University.

El-Boray, K. F. M \& El-Gharabawy, M. M. (1999): Histological characters of ovarian changes of Gerres oyena during the reproductive cycle in Suez Bay, Egypt. Egypt. J. Aquat. Biol. \& Fish., 3(2): 115-129.

EL-Halafawy, M. M. (1995). Reproduction studies on Threadfin Bream, Nemipterus japonicus, in Gulf of Suez. M. Sc. Thesis, Faculty of Science, Suez Canal University.

El-Maghraby, A. M., G. A. Botrous, M. T. Hashem and E. A. Wassef (1981): Hermaphroditism in three sparid fish, Diplodus sargus. L., Diplodus vulgaris, Geoffr., and Oblada melanura L. from the Egyptian Mediterranean waters. Bull. Inst. Oceanogr.\& Fish., ARE, 7(3): 378-385.

EL-Mesiry, G. E. (1993): Reproductive biology and breeding of Rabbit fish, Siganus rivulatus from the Red Sea. B. Sc. Thesis, Faculty of Science, Tanta University. 
Grier, H. J. (1981): Cellular organization of the testis and spermatogenesis in fishes. J. Am. Zool., 21: 345-357.

Henderson, N. E. (1962): The annual cycle in the testis of the eastern brook trout Salvelinus fontinalis (Mitchill). Can. J. Zool., 40: 631-641.

Latif, A. F. A. and B. E. Saady (1973): Reproductive in the Nile Bolti, Tilapia nilotica $L$. sexual cycle of the male. Bull. Inst. Ocean. and Fish., 3:119-142.

Lofts, B. and A. J. Marshal (1957): Cyclical changes in the distribution of the testis lipids of a teleost fish, Esox lucius. Quart. J. Microsc. Sci., 98: 79-88.

Nagahama, Y. (1983): The functional Morphology of teleost gonads. In "fish physiology" . Vol. IXA Academic Press Inc. New York -223-275.

Pollard, D. A. (1972): The biology of land locked form of the normally catadromous salmoniform fish Galaxias maculatus (Jenyns). III. Structure of the gonads. Aust. J. Mar. Freshwat. Res., 23: 17-38.

Ramadan, A. M. (1995). Reproduction studies on Lizard fish, Saurida undosquamis, in Gulf of Suez. M. Sc. Thesis, Faculty of Science, Suez Canal University.

Rastogi, R. k. (1968): Studies on the fish oogenesis I. Histomorphological and cytochemical changes in the oocyte nucleus of Amphipnous cuchia. Int. J. Cytol., 33: 357-369.

Turner, C. L. (1919): The seasonal cycle in spermatogenesis of the Perch. J. Morphol., 32: 681-711.

Zaki, M. I., S. B. Salem, M. M. El-Gharabawy, I. K. EL-Shorbagy and K. F. El-Boray (1994): Seasonal histological changes in the testes of Mugil seheli in Suez Bay. Bull. Nat. Inst. Oceanogr.\& Fish., ARE., 20(1): 211-223. 
Histological changes in the testes of the fish Gerres oyena 91 (Forsskal, 1775) during the reproductive cycle in Suez Bay; Red Sea
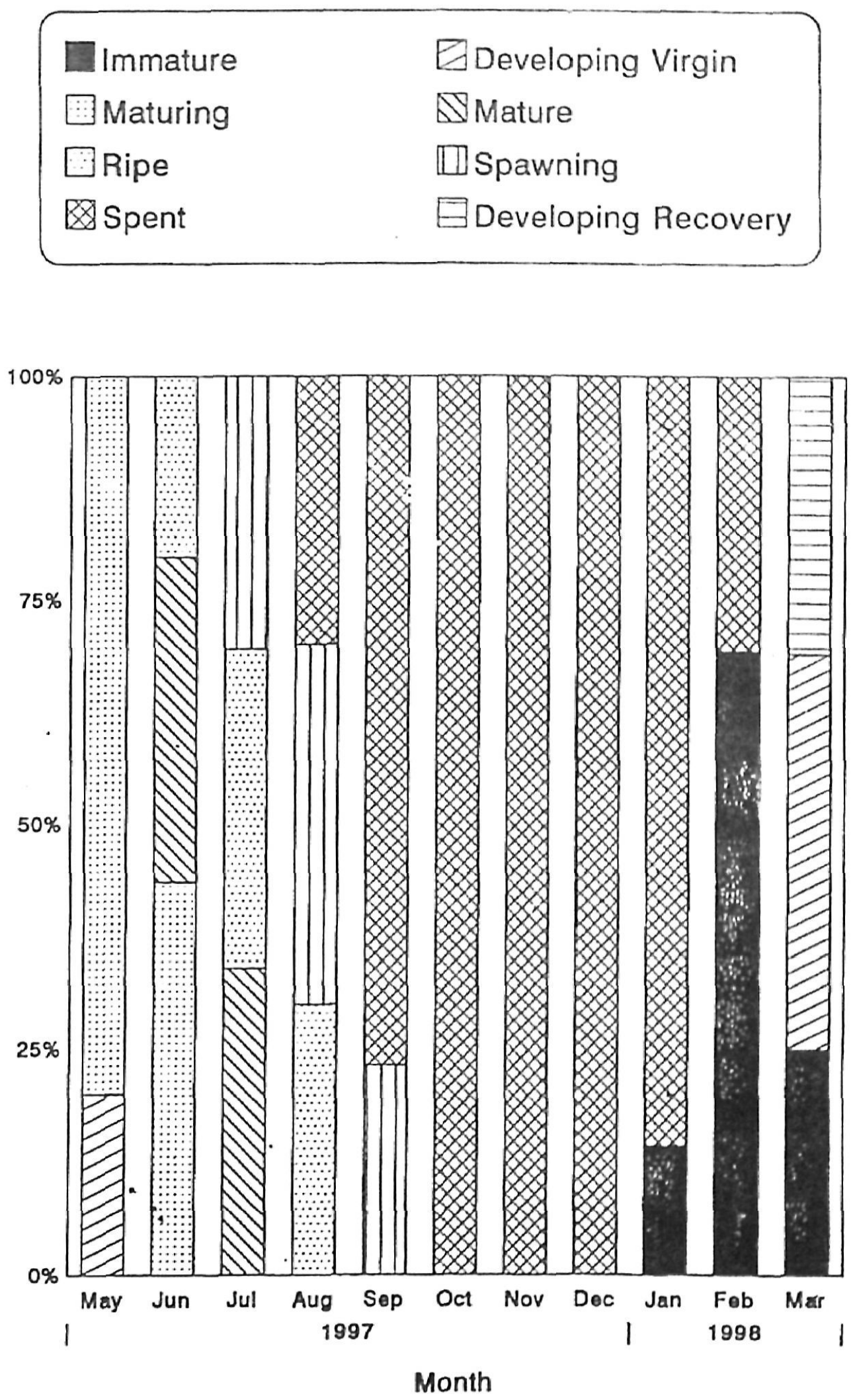

Fig. (10): The monthly distribution of mafurity stages of testes for Gerres oyena in Suez Bay. 

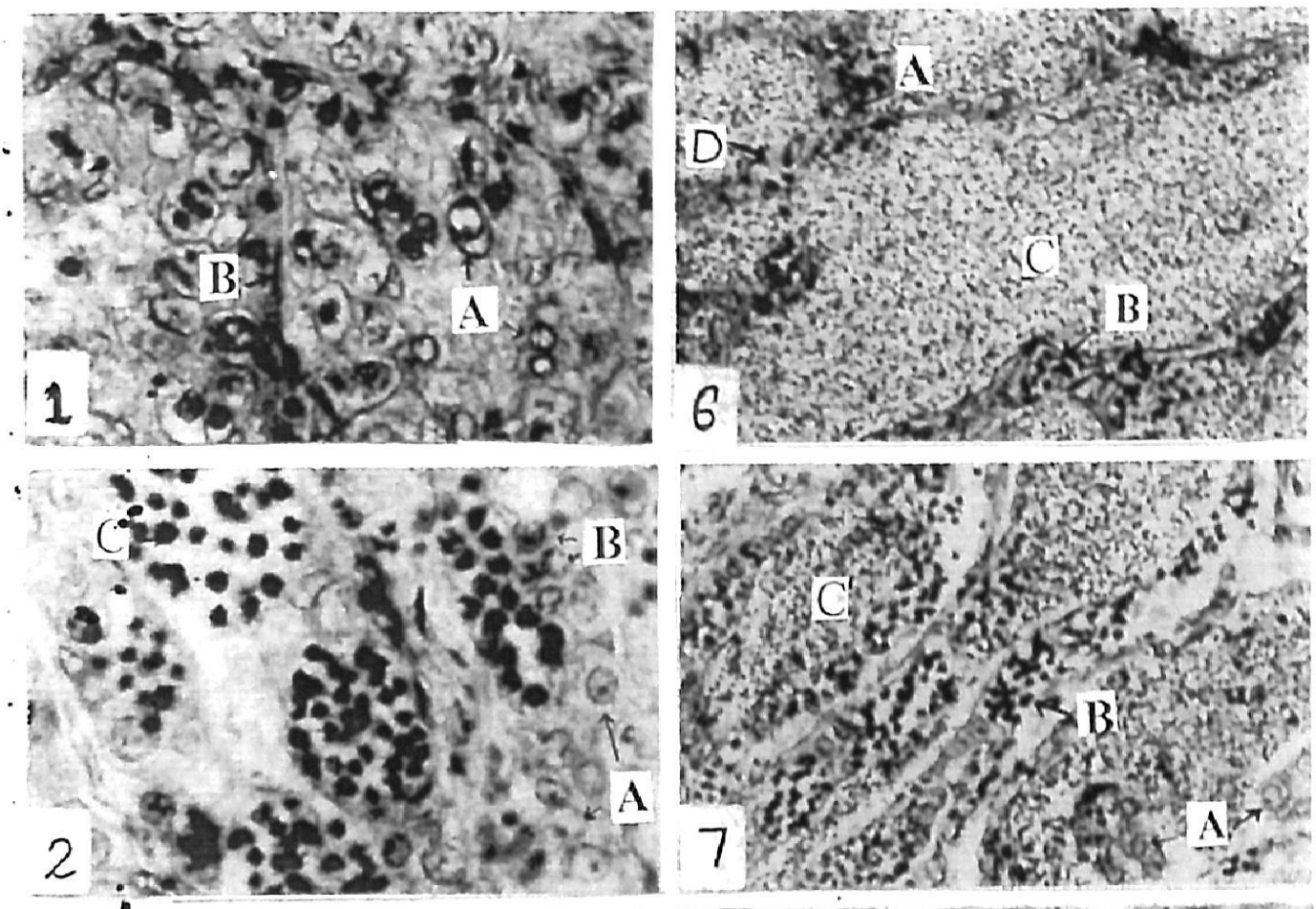

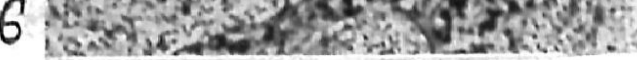

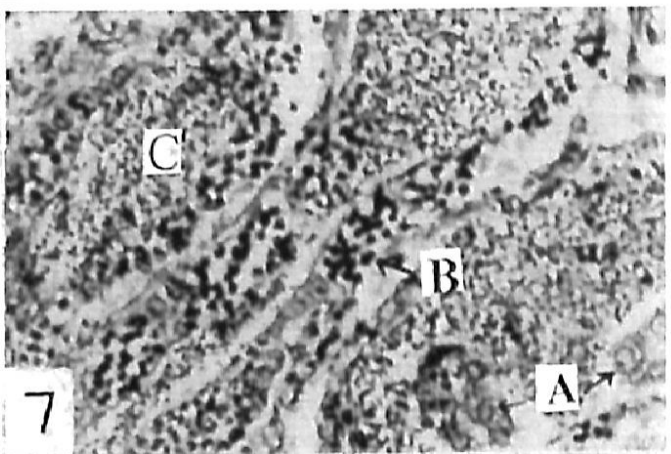

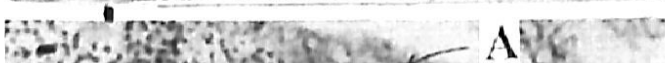

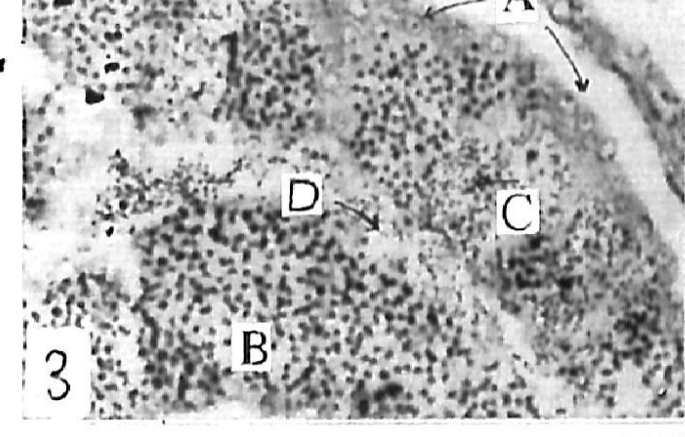
a. 3int

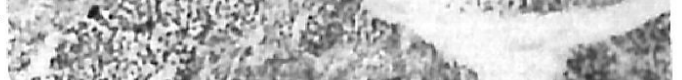

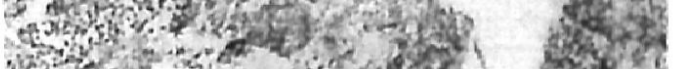

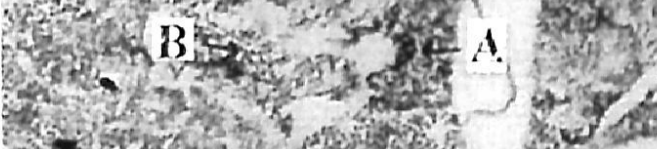
H. 30 , nut Win in pilsh

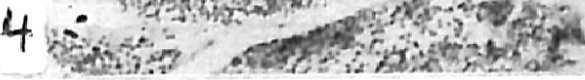
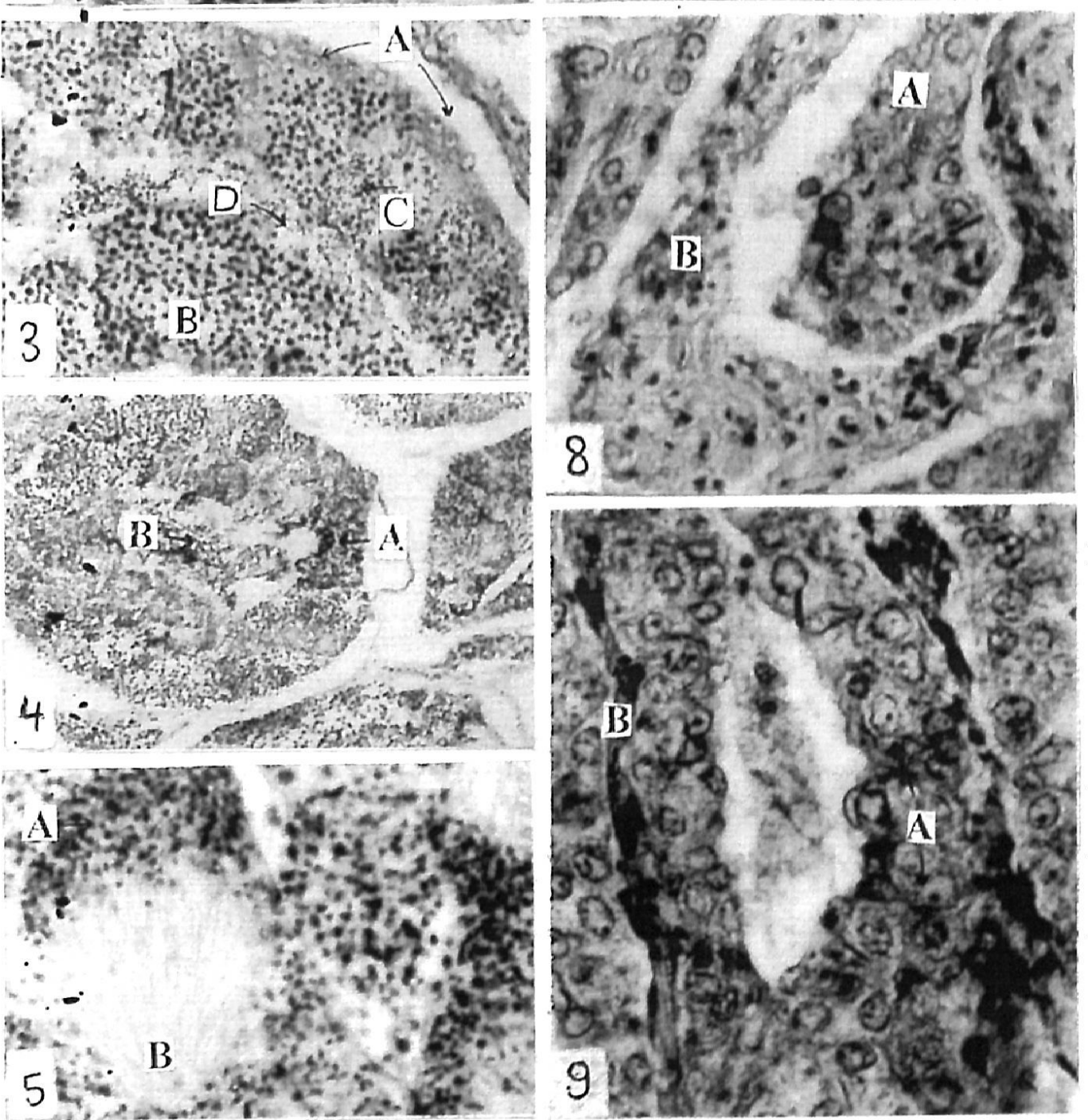